\title{
Heavy Metals Risk Assessment for Potato (Solanum tuberosum L.) Grown in Soils at Borg El Arab Region - Egypt
}

\author{
Saad A. E. Abdelrazek ${ }^{1}$
}

\begin{abstract}
High concentrations of $\mathrm{Co}, \mathrm{Cd}, \mathrm{Cu}, \mathrm{Pb}$, and $\mathrm{Zn}$ were found in potatoes sampled collected from overused phosphate fertilizer - soils, which increased the daily intake of metals in food. However, the ingestion of potatoes from soils affected by phosphate fertilizers posed a low health risk when compared with the health risk index of $<1$ for heavy metals. Nevertheless, the long-term application of phosphate fertilizers, containing high leads of heavy metals, would affect the vegetable production from these fields and raise great concerns about the potential health risks of heavy metal contents of crops grown in such soils. This has been recorded in potatoes grown in Borg El Arab west Alexandria. This study found that long-term phosphate fertilizer use led to a growing accumulation of heavy metals in soils. Thus, heavy metal concentrations should be periodically monitored in vegetables grown in these soils. It would also be beneficial to implement effective remediation technologies to minimize possible impacts on human health.
\end{abstract}

Keywords: Health risk, Heavy metals, Potato, Borg EI Arab, Egypt.

\section{INTRODUCTION}

The food safety has stimulated research regarding the risk associated with consumption of foods contaminated by heavy metals and /or toxins (D'Mello, 2003). This is because food consumption is identified as the major pathway for human exposure to environmental contaminants, accounting for $>90 \%$ of intake compared to inhalation or dermal routes of exposure (Fries, 1995). About $30 \%$ of human cancers are caused by low exposure to initiating carcinogenic contaminants in the diet (Tricker and Preussmann 1990). Potato plants are cultivated in Egypt in different governments because of their extraordinary capacity to adapt to different climatic and soil conditions, and therefore more people consume potato tubers in Egypt. Potato's agronomic efficiency extends range of soil types that can be used for food production and economic development (Abdelrazek 2014). Various agricultural strategies have been suggested for improving nutrition (Graham et al. 2006), including enhancing micronutrient availability through plant breeding, known as bio fortification, and the increased use of fertilizers to improve the nutrient profile of staple foods (Bonierbale et al. 2007). The main trace element input sources for agricultural soils are atmospheric deposition and fertilizers such as phosphates, and animal manures (El-Motaium and Badaway 2000). Fertilizers enhance the natural soil fertility and replace chemical elements taken from soil by harvesting, grazing, leaching, or erosion (Tekin et al. 2001). Phosphate fertilizers are essential for agriculture because they supply farmland with the nutrients required by growing plants (Cajuste et al. 2006; Chen et al. 2007). Heavy metals can occur as impurities in natural materials and minerals, so heavy metals may be present in phosphorus fertilizers and other chemical fertilizers (Elsokkary and Abukila 2011). Long-term application of phosphate fertilizers could result in the accumulation of heavy metals in the soil (Elsokkary, 2012). Crops cultivated on soil rich in heavy metals could take up toxic metals and accumulate them in their tissues. Vegetables contaminated by heavy metals have been documented (Elgala et al 2003). Potatoes are low in fat and rich in several micronutrients, thus, $150 \mathrm{~g}$ potato provides nearly half the daily adult requirement for vitamin C $(100 \mathrm{mg})$. Potatoes are moderate source of iron, and the high vitamin $\mathrm{C}$ content promotes iron absorption. Potatoes are also a good source of vitamins B1, B2 (riboflavin), B3, B5 (pantothenic acid), and B6; foliate; and minerals such as potassium, phosphorus, and magnesium. Potatoes also contain dietary antioxidants that may play a part in preventing diseases related to aging, and dietary fiber which benefits the general health (El-Motaium and Badaway 2000). Approximately $80 \%$ of the potato crop is used for human consumption, which is significantly greater than found with cereals such as corn and wheat. Little information is available on the effects of long-term overuse of phosphate fertilizers and any subsequent accumulation of heavy metals from them by crops. Therefore, the aim of the present study was to provide data on contamination levels of heavy metals and its accumulation in potatoes grown in Borg El Arab area in Egypt The obtained results will be compared with the established guidelines for tolerable levels of heavy metals in food in order to evaluate whether such contamination levels may pose risks to human health (Elsokkary, I. H. 1980).

${ }^{1}$ Soil Salinity Department, Alexandria, Soil, Water and Environment

Research Institute, Agriculture Research Center, Giza, Egypt

Email: Samad_saad@yahoo.com

Received September 17, 2017, Accepted September 30, 2017 


\section{MATERIALS AND METHODS}

\section{Soil sampling and analysis}

Soil samples were collected from the surface layer $(0-20 \mathrm{~cm})$ in Borg El Arab, west Alexandria city, in Egypt. Each sampling area was greater than 5000 feden, and a total of 180 soil samples were collected from potato fields. The soils were air - dried and ground, passed through a 2-mm sieve and kept for analysis. Each sample from each treatment received three replicate analyses. Soil samples were digested using aqua regia $\left(\mathrm{HCl} / \mathrm{HNO}_{3}, 3: 1\right.$ solution)- $\mathrm{HClO} 4(\mathrm{Lu}, 2000)$ and the concentrations of total $\mathrm{Co}, \mathrm{Cd}, \mathrm{Cr}, \mathrm{Cu}, \mathrm{Ni}, \mathrm{Pb}$, and $\mathrm{Zn}$ were determined using inductively coupled plasma atomic emission spectroscopy (ICP-AES).

\section{Crop sampling and analysis}

Potatoes (Solanum tuberosum L.) were collected from the same sites where the soils were collected. Crop samples were washed three to four times with distilled water to remove foreign materials. Crop samples were digested in triplicate to minimize error, with $\mathrm{HNO} 3$ and $\mathrm{HClO}_{4}$ in a 5:1 ratio until a transparent solution was obtained (Allen et al. 1986; Markert, 1996).

The heavy metal concentrations were determined using ICP-AES Data analysis for heavy metal transfer factor from soil to potatoes to determine the transfer of metals from the soil to potatoes. The transfer factors (TF) of metals were calculated as follows (Xue et al. 2011).

$\mathrm{TF}=\mathrm{C}$ potato $\div \mathrm{C}$ soil

Where; $\mathrm{C}_{\text {potato }}$ and $\mathrm{C}_{\text {soil }}$ represent the concentrations of heavy metals in potato extracts and soils on a dry weight basis, respectively

\section{Daily intake of metals}

The human pathway of exposure to heavy metals by the ingestion of contaminated crop has been studied by many researchers (Arora et al. 2008; Chary et al. 2008; Qishlaqi et al. 2008). The daily intake of metals (DIM) by this exposure pathway was determined using the following equation (Xue et al. 2011)

$\mathrm{DIM}=\mathrm{C}$ potato $\mathrm{x} \mathrm{C}$ factor $\mathrm{x} \mathrm{D}$ food intake $\div \mathrm{B}$ average weight (2)

Where; C potato, $\mathrm{C}$ factor, $\mathrm{D}$ food intake, and $\mathrm{B}$ average weight represent the heavy metal concentrations in potatoes (milligram/kilogram) on a dry weight basis, the conversion factor from fresh to dry weight of potatoes is 0.085 (Rattan et al. 2005), the daily intake ( 0.345 and $0.232 \mathrm{~kg}$ per person per day for adults and children, respectively), and the average body weight (55.90 kg for adults and $32.70 \mathrm{~kg}$ for children), respectively (Ge, 1992; Wang et al. 2005).

\section{Health risk index}

A health risk assessment for consumers based on their intake of metal-contaminated crops was characterized using a health risk index (HRI). There was no obvious risk to the exposed population if the HRI is $<1$, but a risk was present if the HRI is $>1$. The HRI was calculated using the following equation (Xue et al. 2011)

$\mathrm{HRI}=\mathrm{DIM} \div \mathrm{RfD}$

Where; the reference oral doses $\mathrm{RfD}$ is for $\mathrm{Cu}, \mathrm{Zn}$, $\mathrm{Ni}, \mathrm{Pb}$, and $\mathrm{Cd}$ which are 0.04, 0. 3, 0.2, 0.0035 and $0.001 \mathrm{mg} \mathrm{kg}-1$ day-1 in this study, respectively (USEPA 2002)

\section{RERSULTS AND DISCUSSION}

\section{Heavy metal concentrations in potatoes}

The concentrations of $\mathrm{Co}, \mathrm{Cd}, \mathrm{Cu}, \mathrm{Ni}, \mathrm{Pb}$, and $\mathrm{Zn}$ $\left(\mu \mathrm{g} \mathrm{g}^{-1}, \mathrm{DW}\right)$ in potatoes and in the soil are shown in (Fig: 1). The average concentrations of heavy metals in crop samples were in the descending order: $\mathrm{Zn}>\mathrm{Ni}>$ $\mathrm{Cu}>\mathrm{Pb}>\mathrm{Co}>\mathrm{Cd}$. Metals, such as $\mathrm{Zn}$ and $\mathrm{Cu}$, are essential metals for humans because they play an important role in biological systems. However, essential heavy metals can produce toxic effects when their intake is excessive. Gopalani et al. (2007) showed that the order of trace metal accumulation in potatoes was $\mathrm{Al}>$ $\mathrm{Fe}>\mathrm{Zn}>\mathrm{Ni}>\mathrm{Mn}>\mathrm{Cu}>\mathrm{Co}>\mathrm{Pb}>\mathrm{Cd}$. The concentrations of heavy metals found in potato tuber samples are presented in Table (1).

Table 1. Range and mean values of heavy metals concentrations ( $\left.\boldsymbol{\mu g} \mathrm{g}^{-1} \mathrm{DW} ; \mathbf{n}=\mathbf{1 8 0}\right)$ in potato tuber of [lants grown in overused phosphate fertilizer soils

\begin{tabular}{lcc}
\hline Heavy metals & Range & Mean \\
\hline $\mathrm{Co}$ & $0.46-12.3$ & 4.0 \\
$\mathrm{Cd}$ & $0.08-4.4$ & 0.9 \\
$\mathrm{Cu}$ & $0.58-20.04$ & 11 \\
$\mathrm{Ni}$ & $0.14-29.6$ & 13.5 \\
$\mathrm{~Pb}$ & $0.21-13.3$ & 4.2 \\
$\mathrm{Zn}$ & $0.25-55.7$ & 22 \\
\hline
\end{tabular}

However, the mean concentrations of $\mathrm{Zn}$ matched those in the published literature (Kumar et al, 2007). Table (2) shows the heavy metal concentrations of the soils, where potatoes were grown. The uptake of heavy metals by potatoes was generally related to the heavy metal levels in the soils (Table 2). Table (3) shows the correlation coefficients for the heavy metal concentrations found in soils and tubers. There were strong correlations among heavy metal concentrations in the potatoes and the metal concentrations in the respective soils where they were cultivated (Abdelrazek, 2014). These results suggest a very simple transfer of heavy metals from soils to plants. 
Table 2. Total concentrations of heavy metals $\left(\mu \mathrm{g} \mathrm{g}^{-1}\right)$ in soils grown with potatoes

\begin{tabular}{lcc} 
Heavy metals & Range & Mean \\
\hline $\mathrm{Co}$ & $2.4-17.03$ & 8.6 \\
$\mathrm{Cd}$ & $0.22-8.1$ & 2.2 \\
$\mathrm{Cu}$ & $1.46-50.11$ & 26.7 \\
$\mathrm{Ni}$ & $0.35-54.9$ & 32.9 \\
$\mathrm{~Pb}$ & $0.55-30.1$ & 10.4 \\
$\mathrm{Zn}$ & $0.64-139.4$ & 55.6 \\
\hline
\end{tabular}

The toxic effect of heavy metals in plants has been studied for many years, but positive and negative results have been reported, depending on the test material and the metal evaluated (White and Claxton 2004). Transfer factors for heavy metals are shown in Table (4). The TF trends for different metals in potatoes grown on overused phosphate-fertilized soils were in the order: $\mathrm{Ni}$ $>\mathrm{Cd}-\mathrm{Cu}-\mathrm{Pb}>\mathrm{Zn}$ reported by (Ashraf et al., 2004). Thus, $\mathrm{Ni}$ had the greatest bioavailability, whereas $\mathrm{Zn}$ had the lowest bioavailability for the potatoes in the study, although the concentrations of As and $\mathrm{Cd}$ were almost 6.5 -fold lower than that of $\mathrm{Zn}$. The results suggest that the uptake of metals by crops was mainly dependent on its bioavailability, rather than its abundance (WHO, 1992).

\section{Risk assessment for crop safety}

Potatoes are an important food and the dietary intake may constitute a major source of long-term low level accumulation of heavy metals in the body, so detrimental impacts may only become apparent after several years of exposure. Regular monitoring of heavy metals in crops is essential to prevent excessive accumulation of these metals via the food chain. Longterm daily intake of contaminated crops is likely to be a detrimental health hazard for consumers. Therefore, we estimated the DIM and HRI for adults and children consuming potatoes grown in overused phosphate fertilized soils (Table 5).

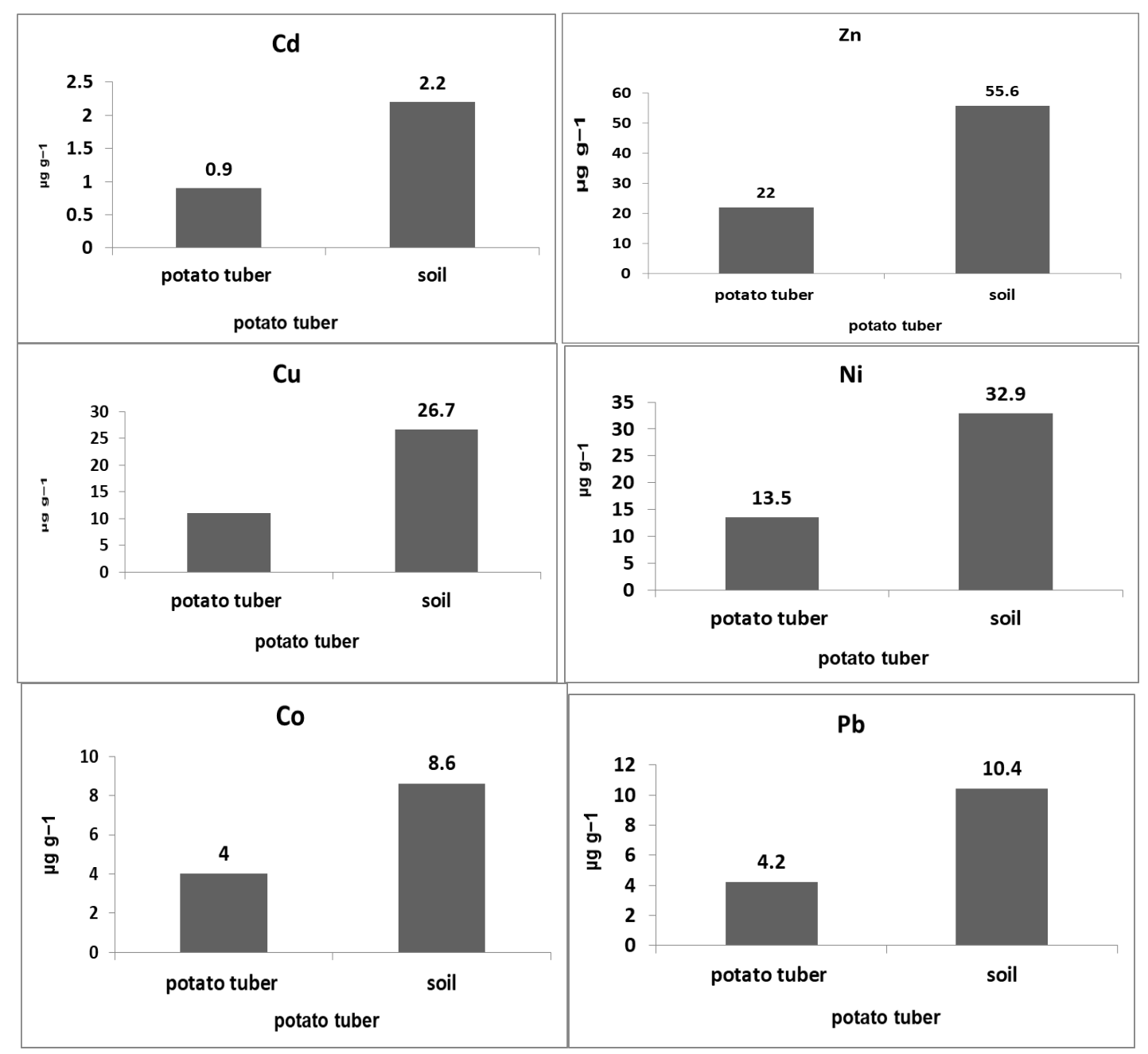

Fig. 1. Range and mean of heavy metals concentration $\left(\mu \mathrm{g} \mathrm{g}^{-1} \mathrm{DW} ; \mathrm{n}=180\right)$ in potato tuber and soil samples 
Table 3. Pearson correlation between the heavy metals contents in soils and tubers*

\begin{tabular}{|c|c|c|c|c|c|c|}
\hline \multirow[b]{2}{*}{ Heavy metals } & \multicolumn{5}{|c|}{ Heavy metals in soils $\left(\mu \mathrm{g} \mathrm{g}^{-1}\right)$} & \multirow[b]{2}{*}{$\mathbf{Z n}$} \\
\hline & Co & $\mathbf{C d}$ & $\begin{array}{c}\mathrm{Cu} \\
\left(\mathrm{mg} \mathrm{kg}^{-1}\right)\end{array}$ & $\mathbf{N i}$ & $\mathbf{P b}$ & \\
\hline Co & 0.91 & 0.74 & 0.32 & 0.94 & 0.85 & 0.83 \\
\hline $\mathrm{Cd}$ & 0.90 & 0.75 & 0.91 & 0.93 & 0.35 & 0.81 \\
\hline $\mathrm{Cu}$ & 0.79 & 0.58 & 0.87 & 0.90 & 0.76 & 0.71 \\
\hline $\mathrm{Ni}$ & 0.79 & 0.58 & 0.88 & 0.90 & 0.76 & 0.70 \\
\hline $\mathrm{Pb}$ & 0.90 & 0.73 & 0.91 & 0.93 & 0.35 & 0.80 \\
\hline $\mathrm{Zn}$ & 0.80 & 0.62 & 0.86 & 0.87 & 0.76 & 0.80 \\
\hline
\end{tabular}

*All values are significant at $1 \%$ level of significance $\mathrm{Co}>\mathrm{Ni}>\mathrm{Cu}>\mathrm{Zn}>\mathrm{Cd}>\mathrm{Pb}$

Table 4. Transfer factors of heavy metals for potatoes grown in overused phosphate fertilizer soils (on dry weight basis)

\begin{tabular}{lcc}
\hline Transfer factor & Range & Mean \\
\hline $\mathrm{Co}$ & $0.19-0.72$ & 0.46 \\
$\mathrm{Cd}$ & $0.36-0.54$ & 0.40 \\
$\mathrm{Cu}$ & $0.39-0.40$ & 0.40 \\
$\mathrm{Ni}$ & $0.40-0.53$ & 0.41 \\
$\mathrm{~Pb}$ & $0.02-0.44$ & 0.40 \\
$\mathrm{Zn}$ & $0.37-0.39$ & 0.39 \\
\hline
\end{tabular}

Table 5. DIM* and HRI** (on dry weight) for individual heavy metals caused by the consumption of potatoes grown in overused phosphate fertilizer soils

\begin{tabular}{lcccccc}
\hline Individuals & $\mathbf{C o}$ & $\mathbf{C d}$ & $\mathbf{C u}$ & $\mathbf{N i}$ & $\mathbf{P b}$ & $\mathbf{Z n}$ \\
\hline Adults & & & & & & \\
DIM & $2 \mathrm{E}-2$ & $4.5 \mathrm{E}-4$ & $5.6 \mathrm{E}-3$ & $6.8 \mathrm{E}-3$ & $2 \mathrm{E}-3$ & $1.1 \mathrm{E}-2$ \\
HRI & - & 0.45 & 0.14 & 0.034 & 0.57 & 0.036 \\
Children & & & & & & \\
DIM & $2 \mathrm{E}-2$ & $5.3 \mathrm{E}-4$ & $6.5 \mathrm{E}-3$ & $7.9 \mathrm{E}-3$ & $2 \mathrm{E}-3$ & $1.3 \mathrm{E}-2$ \\
HRI & - & 0.53 & 0.16 & 0.039 & 0.57 & 0.043 \\
\hline
\end{tabular}

*DIM: Daily intake of metals **HRI: Health risk index

The highest DIMs for the metals $\mathrm{Zn}, \mathrm{Cr}, \mathrm{Ni}$, and $\mathrm{Cu}$, both in adults and children, came from the consumption of potatoes. This indicated that adults and children consuming potatoes grown on overused phosphatefertilized soils ingested high amounts of the metals studied (Sharma et al., 2007).

However, the HRI value of $<1$ indicated a relative absence of health risk from the ingestion of contaminated potatoes. In addition, it was apparent that the intake of a single metal via the consumption of potatoes posed a relatively higher potential health risk for children, when compared with adults. The contamination of crops grown in heavy metal contaminated soils has led to an increased public awareness of health hazards resulting from the consumption of contaminated crops Chary et al., 2008 ) Heavy metals can accumulate in human bodies and produce toxic, neurotoxic, carcinogenic, mutagenic, or teratogenic diseases (El-Gendi, et al 1997). Higher concentrations of metals in crops with higher HRIs or health quotients (HQ) were reported by Agrawal (Agrawal 1999). The HRI values of all tested potatoes were $<1$ in the study area (Table 2), which indicated a relative absence

\section{CONCLUSIONS}

Monitoring of the contaminants of heavy metals contributes to improve food safety and warning of actual and potential food scares and facilitates evaluation of possible health hazards by providing information on levels of environmental pollution in the society. Furthermore, this study focused on the analysis of the heavy metal content and its accumulation in potatoes grown in Borg El Arab area in Egypt. According to our results, long-term phosphate fertilizer use led to moderate accumulation of $\mathrm{As}, \mathrm{Cu}, \mathrm{Pb}$, and $\mathrm{Zn}$ and a significant buildup of $\mathrm{Cd}$ in the soils of the Borg El Arab Area. Potatoes grown in these soils were contaminated with heavy metals and there were strong correlations among heavy metal concentrations in the potatoes and the metal concentrations in the respective soils where they were cultivated. These results suggest a very simple transfer of heavy metals from soils to potatoes and that they were not safe for human consumption. However, the HRI values of $<1$ indicated 
a relative absence of health risks associated with ingestion of the contaminated potatoes.

\section{REFERENCES}

Abdelrazek, S.A.E. 2014. Effect of wastewater irrigation on plant enzymes and soil health in Borg El Arab region, PH.D. Sadat City University

Agrawal, G. D. 1999. Diffuse agricultural water pollution in India.Water Sci and Technol. 39 (3):33-47

Allen, S. E., H. M., Grimshaw, and A. P. Rowland. 1986. Chemica analysis. In P. D. Moore and S. B. Chapman (Eds.), Methods in plant ecology (pp. 285-344). London: Blackwell Scientific.

Arora, M., B. Kiran, S. Rani, A. Rani, B. Kaur and N. Mittal. 2008. Heavy metal accumulation in vegetables irrigated with water from different sources. Food Chem, 111(4), 811-815.

Ashraf, S. M., E. M. M., Gad, S. A. Khorshid and S. M. Fahmy. 2004. Pesticides and heavy metals levels in Egyptian leafy vegetables and some aromatic medicinal plants Food Additives and Contaminants, 21(4): 323-330

Bonierbale, M., W.Amoros, G. Burgos, E. Salas and H. Juarez. 2007. Prospects for enhancing the nutritional value of potato by plant breeding. African Potato Association Conf. Proc. 7(2): 26-46.

Cajuste, L. J., O. C. Garcia, and D. J. Cruz. 2006. Distribution and availability of heavy metals in raw and acidulated phosphate rock-amended soils. Commun Soil Sci Plant Analysis, 37(5): 2541-2552

Chary, N. S., C. T., Kamala, and D. S. Raj. 2008. Assessing risk of heavy metals from consuming food grown on sewage irrigated soils and food chain transfer. Ecotoxicol Environ. Safety, 69(3): 513-524.

Chen, W., A. C. Chang, and L.Wu. 2007. Assessing long-term environmental risks of trace elements in phosphate fertilizers. Ecotoxicol. Environ. Safety, 67(2): 48- 58

D'Mello, J. P. F. 2003. Food safety: Contaminants and toxins (p. 480). Wallingford: CABI Publishing. Dogheim,

Elgala, A. M., M. A. O. M.Elsharawy, and M.Elbordiny. 2003. Impact of sewage water used for irrigation on soil characteristics and heavy metals composition of some grown crops. Egypt. J. Soil Sci., 43:405-419.

El-Gendi, S. A., S.H. Badawy and M.I.D. Helal. 1997. Mobility of some heavy metal nutrients in sandy soils irrigated with sewage effluent. J. Agric. Sci. Mansoura Univ., 22: 3535

El-Motaium, R. A. and S. H. Badaway. 2000. Effect of irrigation using sewage water on the distribution of some heavy metals in bulk and rhizosphere soils and different plant species cabbage plants (Brassica oleracea L.) and orange trees (Citrus sinensis L.) Egypt. J soil Sci., 40: 285.
Elsokkary, I. H. 1980. Contamination of edible parts of seven plant crops and soils by heavy metals in urban areas by air pollution in Alexandria distract, Egypt, In Atmospheric Pollution. Proceeding of the $14^{\text {th }}$ Init Collogium, Paris, France, May 1980, M. M. Benarie (Ed), Studies in Environ. Sci. Elsevire Sci. Pul., pp. 43 -438.

Elsokkary, I. H. 2012. Prospective Strategy for Improving Quality of Agricultural Drainage Water for irrigation, Alexandria Sci Exchange J. v.33: pp306

Elsokkary, I. H. and A. F. Abukila. 2011. Water Quality Evaluation of El Umoum Drain, West Nile Delta of Egypt, During the Period 1989-2010. Alexandria Sci Exchange J. vol.32: pp.454

Fries, G. F. 1995. A review of the significance of animal food products as potential pathways of human exposures to dioxins. J. Animal Sci, 73(6):1639-1650

Ge, K. Y. 1992. The status of nutrient and meal of Chinese in the 1990s. pp. 415-434.

Gopalani, M., M.Shahare, D. S. Ramteke and S. R. Wate. 2007. Heavy metal content of potato chips and biscuits from Nagpur City, India. Bulletin of Environ. Contam. and Toxicol, 79(9): 384-387.

Graham, R. D., R. M. Welch, D. A. Saunders, I. H. OrtizMonasterio, E. Bouis and M. Bonierbale. 2006. Nutritious subsistence food systems. Advan Agron., 92(3): 1-74.

Kumar, N., J. I. Hiren Soni and R. N. Kumar. 2007. Characterization of heavy metals from market vegetables using inductive coupled plasma analyzer. J. Applied Sci. Environ Manage, 11(3): 75-79.

Liu, W. H., J. Z. Zhao, Z. Y. Ouyang, L. Söderlund and G.H. Liu. 2005. Impacts of sewage irrigation on heavy metal distribution and contamination in Beijing, China. Environ Inter., 31(4): 805-812.

Lu, R. K. (2000): Soil and agricultural chemistry analysis (in Chinese) (pp. 321-330).

Markert, B. 1996. Instrumental element and multi-element analysis of plant samples - methods and applications. Chichester: Wiley.

Paraíba, L. C., and K. Kataguiri. 2008. Model approach for estimating potato pesticide bioconcentration factor. Chemosphere, 73(8): 1247-1252.

Qishlaqi, A., F. Moore and G.Forghani. 2008. Impact of untreated wastewater irrigation on soils and crops in Shiraz suburban area, SW Iran. Enviro. Monitoring Assess t, 141(2-3): 257-273.

Rattan, R. K., S. P. Datta, P. K. Chhonkar, K. Suribabu and A. K. Singh. 2005. Long-term impact of irrigation with sewage effluents on heavy metal content in soils, crops and groundwater - a case study. Agric, Ecosystems Enviro, 109: 310-322.

Sharma, R. K., M.Agrawal and F. Marshall. 2007. Heavy metal contamination of soil and vegetables in suburban areas of Varanasi, India. Ecotoxicol and Envir Safety, 66(2):258-266. 
Tekin, T., D.Tekin and M. Bayramoglu. 2001. Effect of ultrasound on the dissolution kinetics of phosphate rock in $\mathrm{HNO}_{3}$. Ultrasonics Sonochemistry, 8(4), 373-377.

Tricker, A. R. and R. Preussmann. 1990. Chemical food contaminants in the initiation of cancer. Proceedings of Nutritional Society, 49:133-144.

US-EPA. 2002. ECO Update, the Role of Screening-Level Risk Assessments and Refining Contaminants of Concern in Baseline Ecological Risk Assessments, US-EPA, United States, Environmental Protection OSWER 9345.014.
Wang, X., T. Sato, B. Xing and S.Tao. 2005. Health risks of heavy metals to the general public in Tianjin, China via consumption of vegetables and fish. Sci. Total Environ., 350(11): 28-37.

White, P. A. and L. D. Claxton. 2004. Mutagens in contaminated soil: A review. Mutation Research, 567(23):227-345.

WHO (World Health Organisation). 1992. Our Plants, Our Health. Geneva. p133

Xue, Z. J., S. Q. Liu, Y. L. Liu and Y. L. Yan. 2011. Health risk assessment of heavy metals for edible parts of vegetables grown in sewage-irrigated soils in suburbs of Baoding City, China. Environ. Monitor. Assess., 11(4): 2204-2206

\section{الملخص العربي - اي}

\section{تقييم مخاطر المعادن الثقيلة على درنة البطاطس التي تزرع في برج العرب}

$$
\text { سعد عبد الصمد السيد عبد الرازق }
$$

المحتوى على المعادن الثقيلة على المدى الطويـلـل ســيؤثز

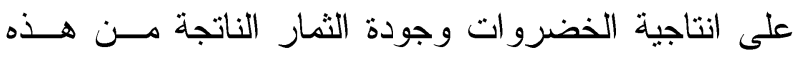

الحقول، ويثير مخاوف كبيرة بـشأن المخــاطر الـصـية

المحتملة نتيجة وجود المعادن الثقيلة من المحاصــيل التــي

تزترع في هذه التزبة، وبناءا عليه ينبغي رصــــ تركيـز ات

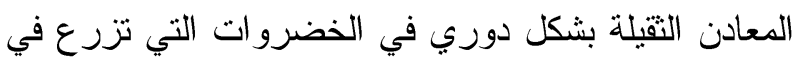

هذه التربة. و لابد من تتفيذ تكنولوجيات معالجة فعالة للتقليل

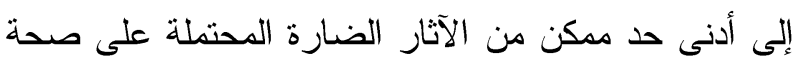

وجدت تركيز ات عاليــة مــن الكوبلـــت، و الكــادميوم،

و النحاس، و الرصاص، و الزنك في عينات البطاطس التى تم جمعها من تربة غنية بالاسمدة الفوسفاتية نتيجة الاســراف فى التسميد بها و المحتوية على كميات من العناصر الثقيلة.

ونتيجة الاستهلاكى المتز ايد للبطاطس فى الغذاء، فإن تتــاول البطاطس من التربة المتضررة من الأسمدة الفوسفاتية يشكل

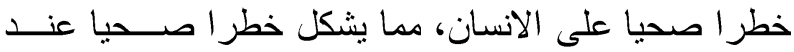

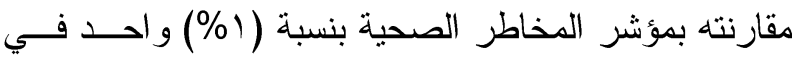
المائة بالنسبة للمعادن الثقيلة، و التسميد بالأسمدة الفوسـفاتية 